\section{The Organization of Markets}

\author{
Göran Ahrne
}

Stockholm University, Sweden

\section{Patrik Aspers}

Uppsala University, Sweden

\section{Nils Brunsson}

Uppsala University, Sweden
Organization Studies 2015, Vol. 36(I) 7-27 (C) The Author(s) 2014 Reprints and permissions: sagepub.co.uk/journalsPermissions.nav DOI: 10.1 | 77//0I708406|4544557 www.egosnet.org/os @SAGE

\begin{abstract}
Markets have sometimes been described as vastly different from and even opposite to formal organizations. But markets and organizations share a similarity as well. Both are organized - by the use of decisions on membership, rules, monitoring, sanctions or hierarchy. Market organization creates differences among markets, and specific dynamics, which can be explained by the actions and interactions of market organizers: profiteers, 'others', sellers and buyers. The concept of market organization is an analytical tool, which can be used for analysing why and how markets are created, why they get their specific form and how they change.
\end{abstract}

\title{
Keywords
}

economic sociology, market, order, organizational forms, partial organization, governance

Over the past thirty years of neoliberalism and deregulation, we have seen an increase in the popularity of markets. New markets have been created and existing ones have expanded. States have privatized some of their operations, allowing vendors to compete for state contracts or customers. Large corporations have outsourced many of their functions, buying services from other companies rather than producing them in-house. The striving for more market solutions has led to the creation of more organizations - the establishment of new firms acting in the new or expanded markets. Large organizations, not least public ones, have increasingly arranged internal markets, with departments selling to and buying from each other. Labour relations within organizations are 
often seen as market relationships between buyers and sellers of labour rather than being perceived as relationships among organizational members. To an increasing extent, organizations rely on consultants and temporary employees rather than long-term employees.

The process of marketization is strongly correlated with the centrality of the market as an institution. In contemporary developed societies, the market - with its concomitant ideas of being a solution to a large set of problems from a great variety of domains - has increasingly become taken for granted. Markets with their imagery of bounded and sovereign 'actors' freely choosing what to buy and sell fit contemporary images of individuals and organizations. At the same time, such contemporary individuals and organizations are not likely to passively accept any feature or outcome of market processes. Instead, they tend to air opinions, to intervene or to suggest that others should intervene in order to organize markets in ways that protect all kinds of social values or special interests. In this respect markets do not differ from contemporary organizations that are also objects for extensive interventions (Meyer \& Bromley, 2013).

This situation actualizes the old questions of why and how markets are fashioned. Social scientists have addressed this question using network, performativity and cultural or institutional approaches, in addition to traditional economic approaches stressing mutual adjustment. We believe that these are valuable contributions, which partly explain much market making. But we also believe that it is difficult to explain contemporary market making without adding the possibility that markets are organized. An organizational approach to markets is not entirely new but we find this approach less developed and recognized than the other approaches. The purpose of this paper is to develop the concept of market organization.

An organizational approach raises questions about the characteristics that constitute organizations and markets. In social science, it has been common to discuss organization and market as irreconcilable opposites. That discussion addresses organization or market, with the two phenomena even handled by different disciplines. Market theory was traditionally developed within economics. Students of organizations have concentrated their interest on formal organizations and have been less inclined to analyse organization outside and among such organizations. Generally, they have treated markets as a non-organized part of the environment of formal organizations.

To regard market and organization as opposites is rarely useful, however, and may even be misleading. Rather, in this article, we discuss the organization of markets. We argue that markets can fruitfully be analysed with the same concepts which students of organization use for analysing formal organizations. In our view, organizing is an activity that need not result in a formal organization. Furthermore, we believe that it is wrong to think of market and formal organization merely as two ready-made co-ordination forms. Like formal organizations, markets can be more organized, less organized and differentially organized.

We begin by arguing that the existing literature is lacking a systematic discussion of the meaning of the notion of organization of markets. In the second section, we suggest a definition of organization, which allows us to discuss organization, not as the opposite of markets but as something that exists within markets as well as within formal organizations. We illustrate how markets within and outside formal organizations are organized. In the third section we argue that there are many organizers of markets, which creates the need for distinguishing among these various types. We suggest a classification based on organizers' interests and positions in the market. Markets are formed by the interplay and conflicts among these types of organizers. In the fourth section, we describe why and how organization matters. We argue that it has a significant impact on the dynamics of markets. And finally, we contrast our analysis with other strands of market literature, and indicate issues for research that are opened up by an organizational perspective on markets. 


\section{Approaches to Market Fashioning}

By market, we refer to both marketplaces and markets for various objects, services and financial instruments. A market is a social structure for the exchange of owner's rights, in which offers are evaluated and priced, and in which individuals or organizations compete with one another via offers (Aspers, 2011). The social structure comprises two roles of exchange - sellers and buyers - both of whom have owner's rights. Actors are considered free to make decisions about their own properties. It is voluntary to participate in exchanges; the buyers must want to buy and the sellers to sell in order for an exchange to occur. Competition refers to the relation between two or more parties aiming for an end that cannot be shared between them without the expense of at least one of the parties.

According to traditional organizational theory and some economists, there is a strong contrast between markets and formal organizations, such as states and firms. They are even seen as independently existing co-ordination forms. Oliver Williamson, for example, argued that 'In the beginning there were markets' (1975, p. 20). Organization is, at most, 'the means of achieving the benefits of collective action in situations in which the price system fails' (Arrow, 1974, p. 33). The strong contrast between market and organization does not deny that the two concepts are intertwined. According to Padgett and Powell $(2012$, p. 8), 'The production and distribution of goods by firms are only half of what is accomplished in markets. Firms are also produced and transformed by the goods and people passing through them.' But both approaches take market and organization for granted and do not discuss the way markets are organized.

The first and most well-known approach to understanding how markets come into existence and change or, for short, are fashioned, is that markets are spontaneously generated: In markets, economic men signal their preferences through prices, and there will be an equilibrium in each market between supply and demand (Hayek, 1973, 1988; A. Smith, 1981). The market is described as a natural consequence of people's mutual adjustment to each other (Lindblom, 2001).

Several other approaches to market fashioning exist, however, developed by both sociologists and economists. Many sociologists share the emphasis on spontaneity and mutual adjustment, subscribing to the idea of markets as a result which can be described as 'order from noise' (Luhmann, 1982, 1988; C. Smith, 2007; White, 1981, 2002, 2008). Other proponents of network sociology argue that markets are stabilized from a set of ties, i.e. networks (e.g. Baker, 1990; Baker, Faulkner, \& Fisher, 1998; Granovetter, 1974; Uzzi, 1997).

Markets do not emerge out of a vacuum, and institutional scholars and those stressing the closely related notion of culture offer insight into the ways in which market fashioning, like any economic action, happens in a context of taken-for-granted scaffolding of culture (DiMaggio, 1990) for market making and market change (Fligstein, 2001; North, 1990). Market culture (Darr \& Pinch, 2013; Pradelle, 2006; Preda, 2009; Zelizer, 2011) explains, for example, some observable variation among different markets in which identical objects are traded. Furthermore, market fashioning presupposes a bedrock of culture, including both general and specific institutions, of which property rights normally backed by states are the most pronounced (North, 1990, 2003).

Although institutions are essential components of any market, an overly strong emphasis on institutions introduces the risk of presenting an exaggerated image of the stability and robustness of contemporary markets. It is not merely institutions that bring order to markets; order is also created by organization, although that order is more precarious and dynamic, partly because it is more dependent on the agency of individuals and organizations.

The literature on market regulation is closer to an understanding of markets as organized. Polanyi used this concept when arguing that 'Regulation and markets, in effect, grew up together' (Polanyi, 1957, p. 71). As indicated by the concept of regulation, the literature has a strong 
emphasis on rules and it concentrates on states as the rule-setters. Other organizers and other ways of organizing are kept in the background. The traditional assumption in the regulation literature is that markets fundamentally consist of spontaneous processes of mutual adjustment, but that states sometimes play a central role in interfering in these processes by setting new rules for the actions and interactions of market actors, as in the case of 'market failures' (Boyer, 1990, 2005; Streeck, 2005).

Fligstein (2001) insisted on the significance of states when analysing the way markets are established, but he also emphasized the role of market actors. He stressed that relationships 'within and across firms and their more formal relations to the state are pivotal for the understanding of how stable markets emerge' (2001, p. 68). According to Fligstein, the creation of markets should be considered a political process, although active fashioning need not involve states; other organizations can organize markets. Fligstein (2008) used the concept of organization frequently, presenting it as a decided order, which implies strategies, control and rules (Fligstein, 2001). Others, too, have discussed market fashioning, using the term 'organization' (Abolafia, 1996; Yakubovich, Granovetter, \& McGuire, 2005).

The literature on performativity (e.g. Callon, 1998; MacKenzie, 2006; MacKenzie \& Millo, 2003; MacKenzie, Muniesa, \& Siu, 2007) is specialized; it stresses the way a certain type of market - exchanges - is constructed essentially with the neoclassical model as blueprint. We take this to be a sign of the importance of organization of markets, although it is not the focus in the performativity literature. That literature has neglected that the neoclassical model was originally mapped on real, highly organized markets (Aspers, 2007).

Although some of these scholars have used the concept of organization in connection with market fashioning, it is not clear what they include in the concept. What is missing from today's literature is a more systematic analysis of the notion of organization. To pursue our approach, we must clarify the concept of organization. Only then can we begin to analyse organized aspects of markets and study how they are organized. We thereby add conceptual clarity and the distinct notion of agency (cf. Beckert, 2010, p. 615) to an organizational approach to market fashioning. In doing so, we attain a way of understanding more of the dynamics of markets and market fashioning.

\section{Organized Markets}

In organization studies and economics, the concept of organization is most often used as equivalent to formal organizations. The concept has also been used in its wider meanings, to describe systematic order in general (Parsons \& Smelser, 1956, p. 246), treated as close to the general meaning of co-operation (Felice, 1984; Lindberg \& Czarniawska, 2006; Weick, 1979) or used for describing systems for the division and integration of labour (Mintzberg, 1979; Perrow, 1986). These definitions of organization can serve as general descriptions of markets, for markets can certainly be seen as forms of systematic order (Callon, 1998), co-operation (Etzioni, 1961; Mises, 1963, p. 143) and divisions of labour (Durkheim, 1984). The definitions are too broad to use as tools for analysing various forms of market organization, however. Instead, drawing on Ahrne and Brunsson (2011), we suggest a narrower definition, which is more precise and analytically sharper and therefore easier to operationalize.

\section{Organized interaction: elements of organization}

In all types of social interaction, one can distinguish five fundamental elements required for the interaction to be continued or repeated: a focused interaction (Goffman, 1972). First, those who interact need to know who is involved in the interaction. Second, they require some common 
notions about what they are doing and how to do it. Third, they need to be able to observe each other to know how to continue. Fourth, they must be able to take measures in order to make others do what they expect them to do. And fifth, they must understand who has the initiative and power.

These five elements are commonly achieved through mechanisms such as cultural norms and traditions, social status or charisma (Ahrne \& Brunsson, 2011). But they are sometimes achieved through decisions: communications to others about what they are expected to do. Such decisions are characteristic of formal organizations. Organizations are formed by decisions, and decisions constitute a fundamental phenomenon of organizations (Luhmann, 2000; March \& Simon, 1958). Organizations regularly decide on the five elements. First, they must decide who is a member and who is not; they are not open to everybody. Second, organizations decide on rules for the actions of its members. Third, they decide how to monitor their members. Fourth, they decide about positive and negative sanctions. And fifth, organizations make decisions about hierarchy; they can decide which of their decisions are binding for their members or prospective members.

Decisions on these elements are fundamental and constitutive for formal organizations. It is through the concomitant decisions, or at least the potential decisions about all interaction elements, that formal organizations are seen as social actors - autonomous actors with collective resources of their own and a unique and recognized identity in relation to other organizations. Decisions on the basic interaction elements can therefore be called elements of organization.

Often, organizations also try to organize their environment deciding about membership, rules, monitoring, sanctions and hierarchy, without necessarily combining them in a formal organization. Even if only one or a few elements are decided upon, we define these decisions as organization, although such a situation is a case of 'partial' organization (Ahrne \& Brunsson, 2011). As is the case with all decisions, it is far from certain that anyone will adapt to the decisions or be strongly affected by them; yet many such decisions have significant effects, not least in markets.

Organization defined in this narrow way is far from covering everything that occurs in formal organizations or in markets. In markets, the five interaction elements are often achieved in ways other than by organization. As any economics textbook reveals, access to markets is limited not only because of decisions on a limited membership, but also because not everyone has the resources to buy, manufacture or sell. The non-organizational equivalent to rules is the norms which emerge in markets and which differ, to a large extent, among markets (Aspers, 2011). Non-organized monitoring, for instance consists of consumers' daily observations of goods and prices in various shops. And a non-organizational equivalent to sanctions in markets is the individual buyer's refusal to buy from some sellers because their products or prices are not acceptable. Power and influence in markets is also achieved through means other than hierarchy - through strong oligopolistic positions, for example. Yet, as we demonstrate in the rest of this section, markets are also organized, and their functioning cannot be fully understood without considering their organization.

\section{Markets within formal organizations}

The use of organization is easy to observe when markets are organized within formal organizations. Exchanges provide a case in point. Exchanges usually take the form of associations or firms. As formal organizations, they have access to all elements of organization. And they use them (cf. Abolafia, 1996; Preda, 2005). All traders who are allowed to deal on a stock exchange must be members of the exchange. It is the exchange that decides on membership. There is a hierarchy, in that decisions can be binding and the possibility of making binding decisions is often used. Detailed rules are set for classifying goods in fixed and clearly separated groups, different types of securities or different qualities of commodities. The rules normally include the way exchanges should be conducted and the way information should be distributed. An exchange is entitled to monitor some 
of its members' activities, and it can issue negative sanctions such as fines, or even temporary or permanent expulsion. As in other organizations, however, not everything the members do is the object of organizational decisions. Members are allowed to decide for themselves when to be sellers and when to be buyers, how much to exchange (although there may be some restrictions) and the prices they are willing to accept.

The fact that many contemporary economists assume that markets appear spontaneously is somewhat surprising, as their market theory is based on Walras's and Marshall's studies of stock exchanges (Aspers, 2011). The extensive organization of stock exchanges was noted by Alfred Marshall more than hundred years ago; he argued that 'The most highly organized exchange are the Stock Exchanges' (Marshall, 1920, pp. 256-7), an idea also expressed by Weber (2000, pp. 326-7) and Walras (1954, pp. 83-4), who spoke of exchanges as perfectly organized markets (Walker, 1996, p. 79). Later economists have argued that exchanges also represent phenomena that come particularly close to the ideal of perfectly competitive markets. Samuelson, for instance, has argued that textbook economic theory applies only to 'a perfectly competitive market where some kind of standardised commodity such as wheat is being auctioned by an organized exchange' (Samuelson, 1969, p. 69).

Exchanges are not the only type of formal organization that organizes markets within their boundaries. Other prominent examples are firms and states that arrange internal markets. Managers decide that units of their organization may exchange goods against payment from other units, a project which involves even more decisions than those required in exchanges (Ackoff, 1993). Both sellers and buyers must be actively constructed. Managers must reconstruct various internal departments into market actors, providing them with some kind of ownership rights, which are valid within the formal organization. These rights must be anchored in the rules of the organization; the organizers cannot rely on the general rules of a state and its laws. An accounting system must be constructed to determine the assets owned by each department and to measure the flow of resources among departments, and decision makers must be appointed to decide about purchases and sales. The management of the organization often sets prices in the form of so-called internal prices. Competition is guaranteed by allowing departments to buy from outside suppliers or from several suppliers within the organization (Althauser, 1989; Halal, 1994).

\section{Organizing markets outside organizations}

Markets within formal organizations are common, and some of them are highly visible, but they are still, empirically, exceptions rather than the rule. Most markets exist outside formal organizations. This does not mean that markets outside organizations are not organized. Many organizations are engaged in organizing markets by using one or several organizational elements. They can direct organizational elements at the goods to be exchanged, to the activities or characteristics of the seller or buyer, to the ways in which exchanges should occur, or even to prices. The elements are used separately or in different combinations. It is not possible or useful here to illustrate market organization in its full breadth and complexity. We can mention only a few examples.

Membership in markets is used to decide who may act as a seller or a buyer in the market. In the ancient guild system, admittance as a seller was decided through membership (Commons, 1909). A modern variant is the requirement in some countries or cities to belong to an organization in order to offer taxi services to the public. People who arrange space in a marketplace decide who will be given space. Membership is also an important element in various trade associations, on both the sellers' and buyers' sides; or in cartels or alliances among sellers, such as airline alliances. Buyers in the form of employers can organize in employers' associations before they negotiate with unions; consumers become members of consumer organizations. 
In contrast to membership, rules can pertain to all aspects of markets. There are rules for the way products should be designed, how sellers or buyers should behave, the prices that should apply, or how the exchange should be made. States are active rule-makers for markets, but so are trade associations and standard-setting organizations. Many of the rules in markets are standards (Brunsson, Jacobsson, \& associates, 2000), which are used to categorize goods into those that comply and those that do not. There are standards for products - for clothing sizes, for coffee (Reinicke, Manning, \& Hagen, 2012), for metrics to be used in the market, for weather risk (Huault $\&$ Ranielli-Weiss, 2011), for screw dimensions, for computer and telephone components. There are also standards for the behaviour of sellers or buyers such as accounting standards, quality standards (Tamm Hallström, 2004), or social responsibility standards (Dubuisson-Quellier, 2013).

Just like rules, monitoring can concern any aspect of markets. There are many organizations, including voluntary associations, which monitor sellers to ensure compliance with various standards (Gourevitch, Lake, \& Stein, 2012; Micheletti, 2003). Certification and accreditation activities are common forms of monitoring in contemporary markets; companies may be certified as quality businesses or socially responsible businesses, for instance. Such rating institutes as Moody's or Standard \& Poor's survey the creditworthiness of businesses (Kerwer, 2002; Rona-Tas \& Hiss, 2011). Newspapers and other media compare prices on consumer commodity markets or investigate the ethical behaviour of companies.

Sanctions comprise rewards or penalties. An example of organized punishment is a decision to boycott certain goods or goods from certain sellers (Micheletti, 2003). In many markets, such as the film market or the book market, awards are common phenomena. Sanctions are sometimes combined with organized monitoring. Certification of an enterprise is a kind of positive sanction, which follows after organized monitoring; refusal of certification is a negative sanction.

Trade associations sometimes use hierarchy, making their decisions binding for their members, as long as they wish to continue as members. States often make binding decisions. But which state shall offer hierarchy is not always obvious. In international trade, it is common for sellers and buyers to agree that disputes shall be settled through the use of hierarchy and where to find the hierarchical element, by indicating that a certain court or other arbitral institute should be applied to (Volckart \& Mangels, 1999).

\section{Varied organization}

In summary, our definition of organization makes it easy to see that there are many ways of organizing markets. There are 120 ways in which the five organizational elements can be combined; and an almost infinite number, if we consider that the organization may be directed to the other aspects of markets - the goods, the sellers or buyers, exchanges and prices.

The elements of organization do not have to be combined with each other. An organizer can use only one or a few of these elements, and one organizer's elements and other organizers of a certain market may or may not add more elements. Traditional product standards issued by ISO, for instance, are rules that are not combined with hierarchy (they are not binding) or with membership (they are available to anyone who wants to apply them) or any other element. On the other hand, some ISO standards such as ISO 9000 have attracted the interest of parties that combine them with monitoring and sanctions in the form of certifications.

Although there is some organizing that is directed at nearly all markets, most of it is specific, which implies that markets differ in their organization - another reason why it is seldom useful to use the concept of 'market' in the singular. Markets, just like formal organizations, vary in the way they are organized and function. 


\section{Market Organizers}

Unlike institutions, organization is tied to agency; it is individuals or organizations that organize. In practice, it is mainly organizations that have the capacity to organize markets. Unlike actors who mutually adjust their behaviour to each other, organizers actively try to change the behaviour of others. The different types of market organization have grown out of the active interventions of organizations, which have tried to organize or reorganize a market in order to reach certain ends. To understand why markets are organized in certain ways at certain times, it is crucial to understand who these market organizers are.

In formal organizations such as exchanges, constitutions restrict who can act as organizers. These restrictions do not prevail outside formal organizations. Many types of organizations - international organizations, states, social movements, trade associations - are involved in organizing markets. In order to describe how markets are organized, it is necessary to describe and analyse the organizers' structural positions as well as their motives and strategies.

Market organizers are often distinguished according to the organizational elements or other more specific service they are offering - standardization organizations, ranking institutes or certification organizations, for instance. In much of social science, it has been usual to emphasize the position and actions of states constructing such classifications as 'state and non-state actors', 'state and private regulation' or 'state regulation and self-regulation'. We find these classifications to be too crude and to be partly misleading if we are to understand why and how various organizations act as market organizers. A state is just one organizer among many; it has several positions and interests. And non-state actors do not form a homogenous group.

In contrast to those approaches, we believe that the most fundamental task is to look for types of organizers with common positions and interests that can be expected to behave in similar ways. We identify three categories of organizers.

The first category discussed here organizes markets in order to make profit. We call this category profiteers. Our second category of market organizers has no economic interests; many of them are non-profit associations. They are involved in the organization of markets on behalf of other persons or organizations, and we call them others. The third category of market organizers consists of those directly involved as sellers or buyers in specific markets.

\section{Profiteers}

Profiteers are individuals and organizations that participate in market organization in order to further their own economic interests. They do not operate as traders, however, in the market in focus - what we call the primary market. Rather they are able to earn money through the organization of the primary market.

One strategy of the profiteer is to organize a market of a certain object or objects, which often implies that a marketplace is organized. The emergence of the modern state was intimately connected to the organization of markets (Schumpeter, 1975), and states have historically organized markets with the key motive of making money in the form of taxes. Rather than allowing buyers and sellers to deal with each other without outside intervention, states and princes established marketplaces in order to gain control over the economy (Masschaele, 1992). To be a prince was virtually identical with the ability to control a market (Weber, 1981, p. 163). As Weber argued, 'princes ... wished to acquire taxable dependents and therefore founded towns and markets' (Weber, 1981, p. 132). Contemporary states currently gain income from monitoring and taxing transactions not only in designated marketplaces, but from all market transactions - not least through value-added tax. 
Today it is common that private firms establish markets and marketplaces in order to make money. eBay is one well-known example (Kashkooli, 2010) of the use of a virtual platform to organize trade, to the economic benefit of the organizer. eBay and similar firms categorize their products, thereby separating them into markets. The organizer decides the rules for membership, sellers are monitored, and sellers that break the rules are sanctioned.

A second way to be a profiteer is sometimes intertwined with the organization of a marketplace: to organize a secondary market based on the existence of a primary market and to act as a seller on the secondary market. This role is taken by intermediaries with privileged knowledge, due to their structural position between sellers and buyers (Burt, 2004). In primary markets, there is exchange of products - stocks, property or antiquities, for instance (Bogdanova, 2011). In the secondary market, stock brokers (e.g. Preda, 2005; C. Smith, 1989), property brokers, agents or auction houses compete for the commissions they receive from their clients for selling or buying in the primary market on their behalf. They organize the primary market by deciding about rules for the exchange, about correct behaviour, and about issues such as who shall monitor the exchange process between sellers and buyers. Models' agencies, for instance, decide the standards for a 'good' model in a way that can be used to set prices (Entwistle, 2002; Mears, 2011), thereby facilitating or even making it possible to contract models.

Intermediaries must strike a balance between bringing sellers and buyers together and keeping them apart. They must bring enough traders together often enough to make a profit, while ensuring that the traders do not start trading on their own and render the intermediaries superfluous. Property brokers and auction houses rarely take great risks, as they never own the securities or the properties. Their profits come from the trade that passes through their hands. Just like states and most arrangers of marketplaces, they are dependent upon and interested in a high volume of trade; they tend to have problems in times of depression or economic crisis.

Another type of profiteer offers specific services in direct relation to market organizing. The increasing number of standards related to administrative processes and production processes has created a large and rapidly growing industry of certification firms earning money from issuing guarantees that organizations comply with quality, environmental or fair trade standards, for instance. Even standards for products now provide a secondary market for certifiers. In the EU system, for example, producers declare that their products are safe for consumption, but in order for the producers to be trusted, they must be certified by accredited certification firms (Gustafsson \& Tamm Hallström, 2013).

Many profiteers legitimize their role as market organizers by arguing that they ultimately work in the interests of the buyers or the sellers. By referring to the arguments of transaction cost theory (Williamson, 1981), it is possible for profiteers to argue that they decrease buyer transaction costs for information searches, for bargaining and for the enforcement of contracts. Brokers and auctioneers can claim to solve the problem of trust by providing a seller or a buyer with a trusted business partner and eliminating the problem of rebuilding trust at the beginning of every business transaction. Standardization, monitoring, certifications and rankings can be justified as means of reducing the buyers' and sellers' information search costs. Auction houses which deal with unique, nonstandardized items such as antiques or art objects can argue that they are able to reduce bargaining costs for their customers.

\section{Others}

Standard economic theory is firmly rooted in the idea of the egoistic 'economic man'. All market actors are presumed to act only in their own self-interest. But there are persons and organizations that try to influence the organization of markets, claiming that they act not in their own interest, but 
in the interests of specific other persons or organizations, or even in the interests of everyone. They have little or no interest in making profit, and they try to help sellers, buyers or whoever is affected by what sellers or buyers do. They are a kind of others, in the sense that Meyer (1996) has given this term, originally coined by G. H. Mead (1964). These others may come from the group that they claim to represent, or they may act on behalf of the group without sharing its predicament. They are directly involved in market organization or they offer views and advice on how other people and organizations should act as organizers.

One type of others is the international governmental organization. Many of them, such as the Organisation for Economic Co-operation and Development (OECD), the International Monetary Fund (IMF), the World Bank and the European Union (EU), are highly active in organizing markets. They have engaged experts to provide concrete advice about how to do it. Many of these experts are trained economists who draw on the neo-classical market model, said to enhance the general good, and possible to use as a template for the organization of real markets (Callon, 1998). The OECD engages economists to monitor the way member states organize their markets and to issue standards for 'bettering' the organization of markets (Marcussen, 2004). The EU has used economic experts to create the so-called inner market (Fligstein, 2008).

Markets are culturally prominent today and, in many cases, ethically controversial (Satz, 2010). It is argued that many markets give rise to so-called 'external effects', many of which are negative - environmental pollution, injustice, health problems, moral decay or misery in general (Satz, 2010). Such arguments are used by others to make claims about what is ethically right and wrong, to support their advice and to justify their own active engagement in market organization. Those who wish to organize markets for these reasons can join associations - environmental movements or temperance societies, for instance. Sometimes the idea is that goods dealt in a certain market should no longer be traded (Bailey, White, \& Pain, 1999), but more often the idea is to use more organizational elements (Alexius \& Tamm Hallström, 2014).

Some others set standards for goods or services, in order to influence the type of goods and how much of a specific good is purchased. Thereby they hope to minimize the production and sale of goods that lead to environmental damage, for example. Standardizers have often combined standard setting with monitoring, or they see to it that profiteers monitor compliance with their standards and perhaps issue certifications and accreditations to the compliers. Sellers that do not conform to certain rules may be sanctioned by boycotts (Micheletti, 2003). But there are also cases in which others join hands with those they want to affect. The Forest Stewardship Council is a multi-stakeholder organization which produces standards for environmentally and socially acceptable timber production; it has sellers, buyers and others as active members (Kristina Tamm Hallström \& Boström, 2010).

By serving as a medium for various interest groups to influence markets, states act as one more other among several. The important role of states for explaining the emergence and form of markets (Fligstein, 2001) should be understood in the light of their position of hierarchy, ultimately due to its monopoly on violence (Weber, 1978). But states do not act only as others and profiteers; they also play the roles of big buyers and sellers.

\section{Sellers and buyers}

Sellers and buyers act on markets that are largely organized by others and profiteers, with whom they may not share interests. The reactions of buyers and sellers to market organizing influence the way markets function. But they often involve themselves in market organizing as well, most often by collaborating with other buyers or sellers. The opposing interests of buyers and sellers and the way these interests are distributed among the actors are crucial for understanding how they try to 
organize markets. There is a significant difference between switch-role markets and fixed-role markets (Aspers, 2009).

In switch-role markets such as stock exchanges, the same person or organization frequently switches from the role of seller to the role of buyer and vice versa. In fixed-role markets, like the market in which car producers sell their products to consumers, buyers and sellers have permanent roles; because of their structurally equivalent roles, sellers share interests with other sellers, and buyers share interests with other buyers (Burt, 1992; Simmel, 1923). The ease with which they can organize a market depends on the form of market. Because buyers and sellers in switch-role markets switch roles, they also switch between the interests of a buyer and the interests of a seller. Consequently, the positions of buyer and seller in this form of market do not provide a stable ground for common organization initiatives.

In fixed-role markets, however, all sellers have a common position, which gives them good reason to engage in organizing for their common interest. Moreover, firms in fixed-role markets cannot easily go from one market to another; producers of cars cannot easily switch to producing butter. The value of the identity and the corresponding cost of actors switching their roles is a reason to use voice rather than exit when facing problems in the market. We thus propose that they will make more attempts to organize their markets rather than to move to different markets.

A high degree of competition is a key source of uncertainty for sellers and buyers (Fligstein, 2001). In fixed-role markets, both sides want competition but typically want less competition on their own side of the market than on the other. To protect their own side and to ensure that those on the other side compete, sellers can differentiate their products (Chamberlin, 1948). Another strategy is to engage in market reorganization - by playing an active role in standardization committees, for instance. Systems of standardization and certification of sellers are ways of diminishing the number of competitors and rendering them more similar and predictable; such systems also decrease the risk of the sudden appearance of new competitors.

Another common reaction is the use of the element of membership, by forming trade associations. By restricting membership to sellers of a certain type, such associations try to reduce competition and uncertainty. Trade associations also use other elements, such as setting rules for members and introducing systems of monitoring and sanctions. As meta-organizations, they sometimes find it difficult to make binding decisions on issues that are controversial among their members (Ahrne \& Brunsson, 2008). Rather, they use standards, voluntary monitoring and positive sanctions such as prizes. On the other hand, their weak hierarchy makes them less threatening to competition for outside observers.

Some of the decisions made in trade associations are illegal in many contemporary economies. Decisions on prices or sales volumes provide examples. Such decisions have outside observers renaming the associations 'cartels', a concept with increasingly negative connotations in many countries (Strandqvist, 2011). On the other hand, trade associations speak with one voice when expressing their demands on other market organizers, and often have greater legitimacy than individual firms do. The official policy of the EU is to speak only to European trade associations - not with individual firms - which has led to the formation of European trade associations in almost every European industry (Jutterström, 2004).

In contemporary economies, sellers often have to engage in organization from their inception, when they try to create a fixed-role market for what they define as a radically new product, thus the ground for a new market. Market organization becomes part of the innovation process (Brunsson \& Tyllström, forthcoming). Sellers have to convince prospective buyers that the new product they want to launch is safe and useful, and that it and its production do not give rise to negative external effects. Thus the seller has reason to seek approval from authorities, environment organizations and the like. New standards have to be formed, as well as new systems of monitoring and perhaps 
certification. An individual seller has reason to support the creation of competitors in order to obtain help in spreading information about and propaganda for the new product, and to avoid the special criticism and requirements that are often directed at monopolists. Competitors can help organizing, perhaps in the role of members of a trade association, formed in advance of any trade. A case in point at the time of writing is the attempt to organize a market for future products using nanotechnology (Delemarle \& Larédo, 2012). The extensive work required in organizing a market for a new product may even lead sellers to try to avoid these costs by representing their product not as new, but as a variation of an existing product which already has an organized market.

Individuals and organizations also organize in their capacity as buyers. They set or support rules that promote competition among sellers or rules that stipulate warranties or request information from sellers, and they engage in monitoring compliance with these rules or organize boycotts of particular goods or sellers. Buyers can create formal organizations such as co-operative associations or associations of industrial buyers or form consumer organizations which make demands on sellers to behave ethically (Baldwin, Cave, \& Lodge, 2010b; Micheletti, 2003). Buyers can also form cartels, which is not uncommon in natural resource markets. Cartels of either buyers or sellers promote the existence of markets or justify their existence (Möllering, 2010); and like sellers, they sometimes engage in market organization before a product is launched. For example, buyers' associations have been engaged in the organization of future nanotechnology markets (Delemarle \& Larédo, 2012).

It is easier to collaborate among few than among many. When markets have few sellers and many buyers, we expect more collaboration on the side of the sellers than on the side of the buyers. Membership recruitment of common formal organizations will then be easier and therefore more frequent among sellers, for instance. When buyers are fewer than sellers, the buyers are easier to organize. The labour market is a case in point. The recruiting of members for employers' associations typically requires less mobilizing efforts than does the formation of unions, although the mobilization of employees has been relatively successful in many countries. Employers' associations and union associations try to influence their market according to their own interests (Korpi, 1983). Many rules and forms of monitoring and sanctions in the labour market result from negotiations among meta-organizations, in which all unions and all employers' organizations are members.

\section{Consequences of Market Organization}

Organization has a deep impact on many markets. Membership in various organizations is a means of strengthening sellers or buyers - providing them with an identity of seriousness or reliability, for example. Membership often involves a more direct collaboration, as is the case with cartels or airline alliances. Standardization reduces variation in goods and services offered and variation in the structure and characteristics of market sellers. Standards make choices easier, and in some cases standards for different qualities of a commodity, such as farming products, even make it possible for sellers and buyers to interact without the physical presence of the commodity. Monitoring increases transparency and attention in selected dimensions. Monitoring affects valuations; it may assure buyers that they are dealing with solid, reliable and ethically acceptable sellers or that they are buying an environmentally sound product (Aspers, 2006; Boström \& Klintman, 2008). The ranking of selling or buying firms in terms of factors such as quality influences how many are willing to trade with them (cf. Podolny, 2005). Sanctions affect the status of actors and goods. A prize or award demonstrates meritorious achievement, often creating increased demand for a product. 
Similar effects can also arise from other market processes and phenomena such as mutual adjustment, networks or institutions. The type of order matters, however. Organization implies a higher degree of visibility and contestation (cf. Stark, 2009) and leads to specific dynamics.

The special effects of organization are rooted in the fact that organization is a decided order. First, decisions make information about market conditions relatively accessible and increase the visibility and transparency of a particular market; in addition to buyers and sellers in the markets, many others learn about these decisions. Decisions about membership in certain markets give a clearer and more complete picture of the sellers or buyers in that market than do other entrance barriers. Decided rules provide more accessible information than do norms, and make it easier for new sellers or buyers to understand what it takes to enter and act in the market. The certification of sellers provides more public information concerning the quality of goods and services than can be attained by asking neighbours or relatives for advice. Standardization makes it easier for buyers to compare prices.

Second, there are specific restrictions on decisions. Social norms place restrictions on what can be decided. There are practices that cannot constitute the content of decisions, which create limits for the organization of markets. It is seldom legitimate in a market context, for example, to decide to create a monopoly (Boltanski \& Thévenot, 2006).

Third, decisions are made by specific individuals or organizations that become responsible for the decision and its consequences. There is someone to turn to if one is dissatisfied with a decision. For every element of organization, someone is responsible - an organizer such as a state, a trade association or an environment association. Such concentrated responsibility stands in contrast to the responsibility dilution which appears if the order is perceived as stemming from mutual adjustment or the development of an institution or a culture. Given that perspective, there are many buyers and sellers, but none of them are responsible for the market. Concrete objects for complaints are largely missing, and there is, instead, talk of 'market forces'.

Fourth, because decisions about the elements of organization concern what others shall do, there is a potential gap between the contents of the decision and what will actually occur; it is not certain that the decision will be complied with. When the norms for how we can talk about markets are somewhat unrealistic, implementation failures will be common. And although what happens in practice is sometimes relatively opaque, the visibility of decisions helps to make these failures known to many. We can expect reports on failed organization to be more common than reports about failed mutual adjustment.

\section{The dynamics of market organization}

Fifth and last, but not least, decisions create specific kinds of dynamics. Scholars have pointed to stabilizing factors in markets such as the tendencies towards equilibriums produced by mutual adjustment or the existence of institutions. They have also pointed to sources of rapid and radical change such as 'external shocks', new technologies or changed preferences. Organization generates a similar pattern although with even more abrupt shifts, creating a radical form of uncertainty.

An organized order always involves a fair degree of instability; it may change and change quickly. New rules for membership in a trade association may change the number of suppliers in a market faster than any mutual adjustment between sellers and buyers can do. Decisions about new standards for a product quickly change the quality of products. Organized monitoring changes the market faster than do the observations of individual customers. When credit rating institutes change their criteria or individual ratings, they immediately change the conditions for obtaining and giving loans. Prizes of high status or popular boycotts change the demand for products overnight. 
Organizers who try to create stability for their way of organizing a market cannot guarantee the result. And organization is not likely to produce equilibriums that guarantee stability.

Organization also makes markets less predictable. An order subject to organization is difficult to predict because it is dependent upon the whim of decision makers and their power. Furthermore, because their decisions are merely attempts, predictions must account for the uncertainty of implementation. Even when decisions have been made and implemented, uncertainty about the duration of their validity remains. Although decisions are attempts to create stability and predictability, allowing the future to be stipulated, they simultaneously increase uncertainty (Brunsson, 1985; Luhmann, 2000). By virtue of the decision, one option for the organization of a market has been selected over another, demonstrating that there are, in fact, options. How do we know that the option decided upon was the best one? So the decision is open for questioning. Other members could have been chosen, standards could have been formulated differently, and other things could have been monitored. Decisions are likely to be contested and stimulate new decisions to organize differently.

Organization brings to markets a more radical uncertainty than what Knight (1921) called uncertainty and risk in markets, which presupposed that norms and rules were stable. But even in a highly organized market, norms can increase predictability to some extent. Social norms restrict what decisions can be made. And when markets are created within formal organizations, predictability increases with the help of constitutions, which at least temporarily restrict the number of decision makers and discourage competition among organizational elements.

In markets outside organizations, however, organizing cannot be restricted to a few, and new organizers may appear and old ones disappear quickly. And it is often easier to make decisions about one element or a few elements than it is to make decisions about all elements. Thus many organizers and many organizing attempts arise, and organizational elements may well compete with each other. Furthermore, if an organizer cannot rely upon all organizational elements, it is more difficult to ensure that the decision will be implemented. It becomes hard to predict who will organize what and how and what impact that organizing will have.

The organization of a market outside organizations typically leads to a compromise rather than to efficiency. It is unlikely that the organization of such a market will be the most efficient solution to anyone's problem. The organization is rarely the fulfilment of the dreams of anyone in particular; nor is the resulting market order, which provides another incentive for further organizing.

For individual market actors, organization adds to the changefulness of their environment, creating prediction difficulties and making it difficult to engage in proactive adaptation to coming changes. Individual positions may be dramatically changed, merely by a decision of one market organizer who refuses membership in a trade organization or a certification or changes a credit rating. It is common, therefore, that corporate managers ask for 'stable rules of the game'. But because it is, in fact, partly a question of 'rules of the game', even dramatic changes can suddenly occur. Greater stability and predictability can be guaranteed only by the institutionalization of these rules or other organization elements (Nee, 2005, p. 64).

\section{Research Implications}

This paper has combined two literatures: the literature on markets, which has touched in a limited way upon the organization of markets; and the literature on organizations, which has only briefly touched upon markets. We have argued that it is fruitful to use the concept of organization in order to understand markets. By breaking down the concept of organization into its constitutive elements, we gained a more detailed analysis of the organization of markets. Markets are more or less organized and they are organized differently. They can exist within or outside formal organizations 
and be organized with few or many organizational elements, directed towards different aspects of markets. There are many organizations involved in organizing markets, and we have suggested a typology based on positions and interests. The organizational aspect of markets influences how and why they change.

In contrast to transaction cost theorists (Thompson, Frances, Levacic, \& Mitchell, 1991; Williamson, 1975), we go beyond the analysis of organization and market as alternative categories. Organization in our sense rarely means that a market will be eliminated. On the contrary, organization is often necessary to bring about a market or to change a prevailing market. The organizational tools we have presented here help to clarify how different elements of organization simplify market exchange. They enable us to add to the analysis of the core question of transaction cost theory: whether a firm will buy a good in the market or incorporate its production in its own organization. Incorporation is just one form of organizing among many. To diminish its transaction costs, a firm may instead, individually or with others, engage in market organization. To take two examples from our previous analysis, the engagement of some companies in standardization work and their demands for certification of their suppliers can be partly understood as attempts to influence their transaction costs. Yet these organizational activities come at a cost, just like incorporation of production into their own organization (Boström, 2012, p. 162) and includes risks of failure, which explains why firms do not always choose to engage in market organization.

We also suggest that the concept of organization presented here could be a useful tool in other fields in which scholars study markets. Although the field of regulation is still highly concentrated in studies of states setting binding rules, there is growing interest in other activities, such as monitoring and sanctions; in other actors, such as standards organizations; and in more voluntary measures (Baldwin, Cave, \& Lodge, 2010a; Baldwin et al., 2010b; Braithwaite \& Drahos, 2000). But for theorizing such a broad phenomenon, the concept of regulation does not seem as adequate and theoretically useful as it was in its original use. And we need to go beyond such general and sweeping concepts as self-regulation, private regulation and soft law. We believe that it would be useful in this context to see states as organizations competing or co-operating with many other organizations in organizing new markets and reorganizing existing ones.

We have offered more detailed tools for analysing market organization than those that have been used by sociologists drawing upon organizational theory. The literature on market performance (Callon, 1998) which, hitherto, dealt only with the performance of switch-role markets as presented by the neo-classical model, can be improved by a more detailed theory of organization to deepen the analysis of these markets. A stronger focus on organization helps us to understand why some markets become switch-role markets and others fixed-role markets.

\section{Research issues}

A period of marketization offers a great opportunity for studying the organization and reorganization of markets. The present state of a market is the result of many processes, but the outcome does not allow us to draw conclusions about what brought it into existence. An empirical analysis of markets must be oriented to processes (Mises, 1963, p. 257) rather than starting with end states. The current order in a market can be partially explained with reference to organizers who have appeared and met with resistance or support and by the fact that one organization has succeeded and another has failed.

It is not a given that identical products or services are traded in the same market. Organizers' efforts often provide better explanations of a market order than does the type of product. Works of art, for example, can be sold in galleries or by auction. Which form becomes dominant depends on 
the initiative and competitive success of different profiteers. Antiques can be sold on eBay rather than in a marketplace that involves the physical handling of objects by an intermediary.

The concept of market organization opens a whole new area of research for scholars interested in organization or markets. The difference between markets and formal organizations is not as dramatic as described in much of the existing literature. During the last half-century or so, many scholars have addressed several fundamental questions about the construction and function of formal organizations. Most of these questions can also be asked about markets, but can be expected to yield answers that differ in some respects. We emphasize three areas for inquiry, all prominent within organization theory: the way organization can create new social contexts, how conflicts and competition among organizers arise and are handled, and the impact of organization.

How can organization contribute to the creation of markets? How can people or organizations become market organizers? Why does a market become organized in a particular way? Why are some markets organized within the context of formal organizations and others are not? Does the structural position of the organizers determine which organizational elements are used? How and to what extent can organization contribute to the creation of market boundaries - distinguishable markets? An equally important issue is the reorganization of markets. How are market reforms triggered, and which organizers come to dominate these reforms?

Whether they operate in new or established markets, organizers have different interests, and often face resistance from other organizers. How do these organizers handle competition between themselves? What conflicts arise between organizers with different positions and interests, and how are these conflicts handled?

Because the organization of markets is based on decisions, their implementation is far from a given. How do organizers make an impact on markets? What strategies do various organizers use to gain influence, and which strategies are successful? To what extent is the implementation of decisions dependent upon the decision maker's legitimacy, and to what extent does it depend on the justifications used? Do the various organizational elements differ in this respect? And by which processes do organizational elements sometimes become taken-for-granted institutions in which active legitimating and justification are no longer necessary? Studying the conditions of legitimacy and institutionalization in processes of market organization over time and across cases will provide information for gaining a better understanding of processes of marketization and market society (Slater \& Tonkiss, 2001). From this perspective, we may also ask specific questions such as: are there, in spite of the modern faith in markets, still areas which are especially difficult to organize as markets, and how are such difficulties overcome? And are there markets that are not organized at all?

Whichever of these areas is chosen for inquiry, we propose to study market organization using a comparative approach in order to gain information on combinations and general trends in a systematic way. We expect that processes of market organization and reorganization differ within organizations and outside organizations and between fixed-role and switch-role markets, but it is a significant issue to discover the precise nature of those differences. And can we distinguish among other types of markets, which differ in their organization?

Research findings on market organization can be compared to findings about formal organizations. How does the organization of a market within an organization differ from other organizing efforts in organizations? And how does the organization of markets outside organizations differ from various kinds of internal organizing processes? Such systematic comparisons can be used as a research strategy for generating further and more precise questions and answers. And the comparisons have a value of their own. Formal organizations and markets are the central forms of the economy, and it is critical to understand their differences and similarities. And the difference is not that one is organized and the other is not. 


\section{Funding}

This research has been funded by Riksbankens Jubileumsfond, Sweden, grant 36520 .

\section{References}

Abolafia, M. (1996). Making markets. Cambridge, MA: Harvard University Press.

Ackoff, R. L. (1993). Corporate Perestroika: The internal market economy. Systems Practice, 6, 239-249.

Ahrne, G., \& Brunsson, N. (2008). Meta-organizations. Cheltenham: Edward Elgar.

Ahrne, G., \& Brunsson, N. (2011). Organization outside organizations: The significance of partial organization. Organization, 18, 83-104.

Alexius, S., \& Tamm Hallström, K. (Eds.) (2014). Configuring value conflicts in markets. Cheltenham: Edward Elgar.

Althauser, R. (1989). Internal labor market. Annual Review of Sociology, 15, 143-161.

Arrow, K. (1974). The limits of organization. New York: W.W. Norton \&Company.

Aspers, P. (2006). Ethics in global garment market chains. In N. Stehr, C. Henning, \& B. Weiler (Eds.), The moralization of the markets (pp. 287-307). London: Transaction Press.

Aspers, P. (2007). Theory, reality and performativity in markets. American Journal of Economics and Sociology, 66, 379-398.

Aspers, P. (2009). Knowledge and value in markets. Theory and Society, 38, 111-131.

Aspers, P. (2011). Markets. Cambridge: Polity Press.

Bailey, C., White, C., \& Pain, R. (1999). Evaluating qualitative research: Dealing with the tension between 'science' and 'creativity'. Area, 31(2), 169-178.

Baker, W. E. (1990). Market networks and corporate behavior. American Journal of Sociology, 96, 589-625.

Baker, W. E., Faulkner, R. R., \& Fisher, G. A. (1998). Hazards of the market: The continuity and dissolution of interorganizational market relationships. American Sociological Review, 63, 147-177.

Baldwin, R., Cave, M., \& Lodge, M. (2010a). The future of regulation. In R. Baldwin, M. Cave, \& M. Lodge (Eds.), The Oxford handbook of regulation. Oxford: Oxford University Press.

Baldwin, R., Cave, M., \& Lodge, M. (2010b). Introduction: Regulation - the field and developing agenda. In R. Baldwin, M. Cave, \& M. Lodge (Eds.), The Oxford handbook of regulation. Oxford: Oxford University Press.

Beckert, J. (2010). How do fields change? The interrelations of instiutions, networks, and cognition in the dynamics of markets. Organization Studies, 31, 605-627.

Bogdanova, E. (2011). Valuing the past: The constitution of the antiques market in Russia. Cologne: University of Cologne.

Boltanski, L., \& Thévenot, L. (2006). On justification: Economies of worth. Princeton, NJ: Princeton University Press.

Boström, M. (2012). The problematic social dimension of sustainable development: The case of the Forest Stewardship Council. International Journal of Sustainable Development \& World Ecology, 19, 3-15.

Boström, M., \& Klintman, M. (2008). Eco-standards, product labeling and green consumerism. Basingstoke: Palgrave Macmillan.

Boyer, R. (1990). The regulation school: A critical introduction. New York: Columbia University Press.

Boyer, R. (2005). How and why capitalisms differ. Cologne: Max Planck Institute for the Study of Societies, Discussion Paper 05/4.

Braithwaite, J., \& Drahos, P. (2000). Global busines regulation. Cambrige: Cambridge University Press.

Brunsson, N. (1985). The irrational organization. Chichester: Wiley.

Brunsson, N., Jacobsson, B., \& associates (2000). A world of standards. Oxford: Oxford University Press.

Brunsson, N., \& Tyllström, A. (forthcoming). When sellers organize markets: Dilemmas and strategies in markets for professional service markets. In N. Brunsson \& M. Jutterström (Eds.), Organizing and reorganizing markets.

Burt, R. (1992). Structural holes: The social structure of competition. Cambridge, Mass.: Harvard University Press.

Burt, R. (2004). Structural holes and good ideas. American Journal of Sociology, 110, 349-399. 
Callon, M. (Ed.) (1998). The laws of the market. Oxford: Blackwell Publishers.

Chamberlin, E. (1948). The theory of monopolistic competition: A re-orientation of the theory of value. Cambridge, MA: Harvard University Press.

Commons, J. (1909). American shoemakers, 1648-1895: A sketch of industrial evolution. Quarterly Journal of Economics, 24, 39-84.

Darr, A., \& Pinch, T. (2013). Performing sales: Material scripts and the social organization of obligation. Organization Studies, 34, 1601-1621.

Delemarle, A., \& Larédo, P. (2012). Organizing markets for nanotechnology products: Investigating firms' collective actions in ISO and the European Code of Conduct. Paper presented at the The organization and re-organization of markets, Stockholm.

DiMaggio, P. (1990). Cultural aspects of economic organization and behavior. In A. F. Robertson \& R. Friedland (Eds.), Beyond the marketplace: Rethinking economy and society. Chicago: Aldine.

Dubuisson-Quellier, S. (2013). A market mediation strategy: How social movements seek to change firms' practices by promoting new principles of product valuation. Organization Studies, 34, 683-703.

Durkheim, É. (1984). The division of labour in society. London: Macmillan.

Entwistle, J. (2002). The aesthetic economy: The production of value in the field of fashion modeling. Journal of Consumer Culture, 2, 317-340.

Etzioni, A. (1961). A comparative analysis of complex organizations: On power, involvement, and their correlates. New York: The Free Press.

Felice, A. (1984). Renaissance performance: Notes on prototypical artistic actions in the age of the Platonic princes. In G. Battcock \& R. Nickas (Eds.), The art of performance: A critical anthology. New York: E.P. Dutton.

Fligstein, N. (2001). The architecture of markets: An economic sociology of twenty-first century capitalist societies. Princeton: Princeton University Press.

Fligstein, N. (2008). Euroclash: The EU, European identity, and the future of Europe. Oxford: Oxford University Press.

Goffman, E. (1972). Relations in public. New York: Harper \& Row.

Gourevitch, P., Lake, D., \& Stein, J. (2012). The credibility of transnational NGOs. Cambridge: Cambridge University Press.

Granovetter, M. (1974). Getting a job: A study of contacts and careers. Cambridge, MA: Harvard University Press.

Gustafsson, I., \& Tamm Hallström, K. (2013). The certification paradox: Monitoring as a solution and a problem. In M. Reuter, F. Wijkström, \& B. Kristensson Uggla (Eds.), Trust and organizations: Confidence across borders. New York: Palgrave.

Halal, W. (1994). From hierarchy to enterprise: Internal markets are the new foundation of management. Academy of Management Executive 8, 69-83.

Hayek, F. v. (1973). Law, legislation and liberty: A new statement of the liberal principles of justice and political economy, Volume 1, Rules and order. Chicago: University of Chicago Press.

Hayek, F. v. (1988). The collected works of Friedrich August Hayek, Volume I, The fatal conceit: The errors of socialism. London: Routledge.

Huault, I., \& Ranielli-Weiss, H. (2011). A market for weather risk? Conflicting metrics, attempts at compromise, and limits to commensuration. Organization Studies, 32, 1395-1419.

Jutterström, M. (2004). Att påverka beslut - företag i EUs regelsättande. Stockholm: EFI.

Kashkooli, K. A. (2010). The making of a modern market: eBay.com. Ann Arbor, MI: ProQuest.

Kerwer, D. (2002). Standardizing as governance: The case of credit rating agencies. In A. Héritier (Ed.), Common goods: Reinventing European and international governance (pp. 293-315). Lanham, MD: Rowman \& Littlefield.

Knight, F. (1921). Risk, uncertainty and profit. Boston: Houghton Mifflin Company.

Korpi, W. (1983). The democratic class struggle. London: Routledge \& Keegan Paul.

Lindberg, K., \& Czarniawska, B. (2006). Knotting the net of action, or organizing between organizations. Scandinavian Journal of Management, 22, 292-306. 
Lindblom, C. (2001). The market system: What it is, how it works, and what to make of it. New Haven, CT: Yale University Press.

Luhmann, N. (1982). The differentiation of society. New York: Columbia University Press.

Luhmann, N. (1988). Die Wirtschaft der Gesellschaft. Frankfurt am Main: Suhrkamp.

Luhmann, N. (2000). Organisation und Entscheidung. Opladen: Westdeutscher Verlag.

MacKenzie, D. (2006). An engine, not a camera: How financial models shape markets. Cambridge: Cambridge University Press.

MacKenzie, D., \& Millo, Y. (2003). Constructing a market, performing theory: The historical sociology of a financial derivatives exchange. American Journal of Sociology, 109, 107-145.

MacKenzie, D., Muniesa, F., \& Siu, L. (Eds.) (2007). Do economists make markets? On the performativity of economics. Princeton, NJ: Princeton University Press.

March, J., \& Simon, H. (1958). Organizations. Cambridge, MA: Blackwell.

Marcussen, M. (2004). OECD governance through soft law. In U. Mörth (Ed.), Governance and regulation: An interdisciplinary analysis (pp. 103-126). Cheltenham: Edward Elgar.

Marshall, A. (1920). Industry and trade: A study of industrial technique and business organization; of their influences on the conditions of various classes and nations. London: Macmillan.

Masschaele, J. (1992). Market rights in thirteenth-century England. English Historical Review, 107(422), 78-89.

Mead, G. (1964). George Herbert Mead on social psychology. Chicago University of Chicago Press.

Mears, A. (2011). Pricing beauty: The making of a fashion model. Berkeley: University of California Press.

Meyer, J. (1996). Otherhood, the promulgation and transmission of ideas of the modern organizational environment. In B. Carniawska \& G. Sevon (Eds.), Translating organizational change (pp. 241-252). New York: Walter de Gruyter.

Meyer, J., \& Bromley, P. (2013). The worldwide expansion of 'organization'. Sociological Theory, 31, $366-389$.

Micheletti, M. (2003). Political virtue and shopping: Individuals, consumerism, and collective action. New York: Palgrave Macmillan.

Mintzberg, H. (1979). The structuring of organizations. Englewood Cliffs, NJ: Prentice-Hall.

Mises, L. v. (1963). Human action: A treatise on economics (3rd edition). Chicago: Henry Regnery Company.

Möllering, G. (2010). Kartelle, Konsortien, Kooperationen und die Entstehung neuer Märkte. Zeitschrift für betriebswirtschaftliche Forschung, 62, 770-796.

Nee, V. (2005). The new institutionalism in economics and sociology. In N. Smelser \& R. Swedberg (Eds.), The Handbook of economic sociology (pp. 49-74). Princeton, NJ: Princeton University Press.

North, D. (1990). Institutions and their consequences for economic performance. In K. Cook \& M. Levi (Eds.), The limits of rationality (pp. 383-401). Chicago: Chicago University Press.

North, D. (2003). Markets. In J. Mokyr (Ed.), The Oxford encyclopedia of economic history (Vol. 3, pp. 432-439). Oxford: Oxford University Press.

Padgett, J., \& Powell, W. (2012). The emergence of organizations and markets. Princeton, NJ: Princeton University Press.

Parsons, T., \& Smelser, N. (1956). Economy and society. Glencoe, IL: The Free Press.

Perrow, C. (1986). Complex organizations: A critical essay. New York: McGraw-Hill.

Podolny, J. (2005). Status signals: A sociological study of market competition. Princeton, NJ: Princeton University Press.

Polanyi, K. (1957). The great transformation. Boston, MA: Beacon.

Pradelle, M. (2006). Market day in Provence. Chicago: University of Chicago Press.

Preda, A. (2005). Legitimacy and status groups in financial markets. British Journal of Sociology, 56, 451-457.

Preda, A. (2009). Framing finance. Chicago: Chicago University Press.

Reinicke, J., Manning, S., \& Hagen, O. v. (2012). The emergence of a standards market: Multiplicity of sustainability standards in the coffee industry. Organization Studies, 33, 791-814. 
Rona-Tas, A., \& Hiss, S. (2011). Forecasting as valuation: The role of ratings and predictions in the subprime mortgage crisis in the United States. In J. Beckert \& P. Aspers (Eds.), The worth of goods: Valuation and pricing in the economy. Oxford: Oxford University Press.

Samuelson, P. (1969). Economics: An introductory analysis, 6th edition. New York: McGraw Hill.

Satz, D. (2010). Why some things should not be for sale: The moral limits of markets. Oxford: Oxford University Press.

Schumpeter, J. (1975). Capitalism, socialism and democracy. New York: Harper \& Row.

Simmel, G. (1923). Soziologie, Untersuchungen über die Formen der Vergesellschaftung. München; Leipzig: Duncker \& Humblot.

Slater, D., \& Tonkiss, F. (2001). Market society: Markets and modern social theory. Cambridge: Polity.

Smith, A. (1981). An inquiry into the nature and causes of the wealth of nations. Indianapolis: Liberty Press.

Smith, C. (1989). Auctions: The social construction of value. Berkeley: University of California Press.

Smith, C. (2007). Markets as definitional practices. Canadian Journal of Sociology, 32, 1-39.

Stark, D. (2009). The sense of dissonance: Accounts of worth in economic life. Princeton: Princeton University Press.

Strandqvist, K. (2011). The Swedish pipe and tube market - Attempts to Organize and Resistance: Studying the pipe and tube wholesalers over the legislation process leading to the New Competition Act of 1953. Paper presented at Ekonom-historiska årsmötet, Gothenburg.

Streeck, W. (2005). The sociology of labor markets and trade unions. In N. Smelser \& R. Swedberg (Eds.), The handbook of economic sociology, 2nd edition (pp. 254-283). Princeton, NJ: Princeton University Press.

Tamm Hallström, K. (2004). Organizing international standardization - ISO and the IASC in quest of authority. Cheltenham: Edward Elgar.

Tamm Hallström, K., \& Boström, M. (Eds.) (2010). Transnational multi-stakeholder standardization: Organizing fragile non-state authority. Cheltenham: Edward Elgar.

Thompson, G., Frances, J., Levacic, R., \& Mitchell, J. (Eds.) (1991). Markets, hierarchies and networks: The coordination of social life. London: SAGE Publications.

Uzzi, B. (1997). Social structure in interfirm networks: The paradox of embeddedness. Administrative Science Quarterly, 42, 35-67.

Volckart, O., \& Mangels, A. (1999). Are the roots of the modern lex mercatoria really medieval? Southern Economic Journal, 65, 427-450.

Walker, D. (1996). Walra's market models. Cambridge: Cambridge University Press.

Walras, L. (1954). Elements of pure economics, or the theory of social wealth. London: George Allen \& Unwin Ltd.

Weber, M. (1978). Economy and society: An outline of interpretive sociology (2 volumes; G. Roth \& C. Wittich, Trans.). Berkeley: University of California Press.

Weber, M. (1981). General economic history. New Brunswick, NJ: Transaction Publishers.

Weber, M. (2000). Stock and commodity exchanges. Theory and Society, 29, 305-338.

Weick, K. (1979). The social psychology of organizing. Reading, MA: Addison-Wesley.

White, H. (1981). Where do markets come from? American Journal of Sociology, 87, 517-547.

White, H. (2002). Markets from networks: Socioeconomic models of production. Princeton, NJ: Princeton University Press.

White, H. (2008). Identity and control: How social formations emerge. Princeton, NJ: Princeton University Press.

Williamson, O. (1975). Markets and hierarchies: Analysis and antitrust implications. New York: Free Press.

Williamson, O. (1981). The economics of organization: The transaction cost approach. American Journal of Sociology, 87, 548-577.

Yakubovich, V., Granovetter, M., \& McGuire, P. (2005). Electric charges: The social construction of rate systems. Theory and Society, 34, 579-612.

Zelizer, V. (2011). Economic lives: How culture shapes the economy. Princeton, NJ: Princeton University Press. 


\section{Author biographies}

Göran Ahrne is Professor of Sociology at Stockholm University and has published a number of books and articles on social theory and organization theory.

Patrik Aspers is Professor of Sociology at Uppsala University, and his main focus is sociology of markets, on which he has written extensively.

Nils Brunsson is Professor of Management at Uppsala University and an honorary member of EGOS. His publications include books and articles on decision making, administrative reforms, standardization, metaorganizations and partial organization.

The three authors participate in the research programme Organizing Markets, conducted at Score (Stockholm Centre for Organizational Research). 